\title{
PEMIKIRAN EKONOMI IBN KHALDUN; PENDEKATAN DINAMIKA SOSIAL-EKONOMI DAN POLITIK
}

\author{
IBN KHALDUN'S ECONOMIC THOUGHT; \\ SOCIAL-ECONOMIC AND POLITICAL DYNAMICS APPROACH
}

\author{
Yosi Aryanti \\ STIT Ahlussunnah Bukittinggi \\ Jl. Diponegoro No. 08 Ateh Tambuo Aur Kuning Bukittinggi.Telp. (0752) 34130 \\ e-mail : ochies1978@gmail.com
}

Naskah diterima 02 Juli 2018, di-review 01 Agustus 2018, disetujui 09 Nopember 2018.

\begin{abstract}
Economic activities oriented to the Islamic Economic system are increasingly widespread in various countries, including Indonesia. Speaking of Islamic Economic theory, it cannot be separated from the thoughts of figures who have contributed to the foundation and principles of Islamic economics. Ibn Khaldun is one of the greatest scholars who have made a significant contribution to economic development. This figure cannot be separated from the Islamic values. Through deep and critical discussion of his work, it will be seen in the ethical view of religion that accommodates the teachings of Islamic economics, and the other side of the human family to recognize nature to pursue economic activities. This type of research is library research. Data were analyzed through a philosophical approach and described deductively. This study aims to reveal the contribution of Ibn Khaldun's thoughts on the development of Islamic Economics like market mechanisms, profits, division of labor and international trade, public finance, state wealth standards, the concept of money and welfare the community.
\end{abstract}

Keywords: Islamic economic, Ibnu Khaldun's thought, welfare

\begin{abstract}
Abstrak: Kegiatan ekonomi yang berorientasi pada sistem Ekonomi Islam semakin meluas di berbagai negara, termasuk Indonesia. Berbicara tentang teori Ekonomi Islam, itu tidak dapat dipisahkan dari pemikiran tokoh-tokoh yang telah berkontribusi terhadap prinsip-prinsip ekonomi Islam. Ibnu Khaldun adalah salah satu cendekiawan terbesar yang telah memberikan kontribusi signifikan terhadap pembangunan ekonomi. Tokoh ini tidak dapat dipisahkan dari nilai-nilai Islam. Melalui kajian yang mendalam tentang karyanya, akan tergambar pandangan etika agama yang mengakomodasi ajaranajaran ekonomi Islam. Jenis penelitian ini adalah penelitian kepustakaan. Data-data dianalisis melalui pendekatan filosofis dan dijelaskan secara deduktif. Penelitian ini bertujuan untuk mengungkapkan kontribusi pemikiran Ibnu Khaldun tentang perkembangan Ekonomi Islam. Peneliti menganalisis teori Ekonomi Islam yang berasal dari pemikiran Ibnu Khaldun, dengan menggunakan pendekatan dinamika sosial-ekonomi dan politik, beberapa dari teori ini termasuk mekanisme pasar, keuntungan, pembagian kerja dan perdagangan internasional, keuangan publik, standar kekayaan negara, konsep uang dan kesejahteraan masyarakat.
\end{abstract}

Kata kunci: ekonomi Islam, pemikiran Ibnu Khaldun, kesejahteraan

\section{PENDAHULUAN}

P endekatan ekonomi Ibn Khaldun yang terdapat dalam mukaddimah tidak terlepas dari sebuah pengamatan terhadap sejarah manusia. Fokus kajian Ibn Khaldun adalah manusia, ia memahami bahwa kejayaan atau keruntuhan sebuah dinasti atau peradaban sebagai faktor yang terkait erat dengan kesejahteraan atau kesengsaraan rakyat. Di dalam analisis Ibnu Khaldun, kejayaan dan keruntuhan bukan hanya tergantung pada variable-variabel ekonomi, melainkan juga pada sejumlah faktor 
lain yang turut menentukan kualitas individu, masyarakat, penguasa, dan lembaga-lembaga. Karena itu mukaddimah mencoba untuk menentukan faktor-faktor yang mempengaruhi kualitas tersebut dengan melakukan analisis terhadap faktor yang berhubungan, seperti: peran faktor moral, psikologis, politik ekonomi, sosial demografi, dan sejarah dalam fenomena jatuh bangunnya suatu pemerintahan ataupun suatu peradaban. Analisis yang interdisipliner dan dinamis dari Ibn Khaldun, tercermin dalam rumusannya yang menghubungkan semua variabel-variabel sosial, ekonomi dan politik. Variabel-variabel tersebut berada dalam satu lingkaran yang saling tergantung karena satu sama lain saling mempengaruhi.

Pemikiran ekonomi Ibn Khaldun tersebut cukup relevan untuk dapat menjawab berbagai persoalan. Ibn Khaldun sering kali secara eksplisit maupun implisit mengkritik perilaku bermewahmewahan suatu masyarakat yang telah maju sebagai titik balik merosotnya kehidupan ekonomi suatu masyarakat atau peradaban hingga menuju keruntuhannya. Dari konteks besar pemikirannya tersebut banyak teori-teori ekonomi yang dapat digali yang sebenarnya berpijak pada pengamatan empirisnya terhadap perilaku ekonomi berbagai masyarakat yang ditemuinya. Karena teori-teori ekonomi Ibn Khaldun bisa dimasukkan kedalam kategori ilmu ekonomi positif (positive economics) yang didasarkan pada pengamatan empiris dengan pendekatan sosiologis. Secara garis besar perhatiannya pada masalah ekonomi bertolak dari adanya interelasi dalam perekonomiannya secara makro antara beberapa komponen yaitu syariat (agama), pemerintah, rakyat, harta (kondisi ekonomi), aktivitas ekonomi, dan keadilan. Interelasi yang dimaksudkan di sini adalah lebih dari sekedar relasi adanya hubungan resiprokal antara komponen - komponen tersebut. Mengenai Ibn Khaldun sendiri, dia lebih tersohor sebagai seorang sejarawan dan sosiolog. Terlahir dan melalui masa hidup dalam suasana perpolitikan yang tidak menentu, dia juga tampil sebagai seorang negarawan yang handal. Tapi tidak sedikit pula yang mengakui dan mengapresiasi keahliannya dalam bidang ekonomi. Terkait dengan ketokohannya yang menonjol di bidang sejarah dan sosiologi, untuk mempelajari pemikiran ekonomi ulama dari Tunisia itu mau tidak mau juga harus melibatkan kedua bidang tersebut. Sebagian besar teori ekonomi yang dikemukakan integral dengan pemikiran-pemikiran sosiologinya yang berangkat dari pengamatan historis. Ibn Khaldun sendiri memperlihatkan kesan itu dalam ungkapannya bahwa perbedaan hal ihwal penduduk adalah akibat dari perbedaan cara mereka memperoleh penghidupan (caracara produksi). Ini berarti baginya ekonomi memiliki peran yang cukup besar dalam ikut menentukan arah perjalanan sejarah. Di atas itu semua, yang tidak boleh dilupakan Ibn Khaldun adalah salah seorang ulama Islam terbesar yang kedalaman pengetahuan agamanya tidak perlu diragukan lagi. Dalam bidang pengetahuan agama Islam, beliau sejak kecil telah digembleng oleh banyak ulama besar, saat itu salah satunya ayah beliau sendiri. Menurut Syathial-Husri, dalam karyanya Dirasat'an Muqaddimah Ibn Khaldun, sebagaimana dikutip Zainabal-Khudhairi, 
kandungan Mukadimah menunjukkan secara jelas bahwa penyusunnya adalah seorang mukmin yang taat dan mempercayai Allah dan Islam secara mendalam. Ibn Khaldun dapat juga dikatakan sebagai seorang ilmuwan yang tidak pernah mempertanyakan dan meragukan kebenaran syariat Islam. Dari sini dapat dimaklumi bahwa seempiris apapun hasil pengamatannya, tidak terlepas dari sentuhan nilai-nilai Islam yang melekat dalam dirinya. Melalui pembacaan secara mendalam dan kritis terhadap karyanya tersebut akan terlihat pandangan etis-religiusnya dalam bidang ekonomi yang mengakomodasi ajaranajaran Islam di satu sisi dan mengakui eksistensi "fitrah" manusia untuk melakukan aktivitasaktivitas ekonomi di sisi lain.

\section{METODE PENELITIAN}

Penelitian ini termasuk jenis penelitian kepustakaan (library research) dengan pendekatan kualitatif. Untuk memperoleh informasi tentang berbagai aspek yang berkaitan dengan persoalan penelitian dilakukan penelaaahan dengan menelaah buku-buku, jurnal, dan atau sumbersember lainnya yang relevan dengan pembahasan dengan tujuan untuk sampai pada kesimpulan tentang pemikiran ekonomi Ibn Khaldun melalui pendekatan dinamika sosial-ekonomi dan politik.

\section{PEMBAHASAN DAN HASIL}

\section{Pemikiran Ekonomi Ibn Khaldun}

Ibn Khaldun membahas aneka ragam masalah ekonomi yang luas, termasuk ajaran tentang tata nilai, pembagian kerja, sistem harga, hukum penawaran dan permintaan, konsumsi dan produksi, uang, pembentukan modal, pertumbuhan penduduk, makro ekonomi dari pajak dan pengeluaran publik, daur perdagangan, pertanian, industri dan perdagangan, hak milik dan kemakmuran, dan sebagainya. Ia juga membahas berbagai tahapan yang dilewati masyarakat dalam perkembangan ekonominya. Kita juga menemukan paham dasar yang menjelma dalam kurva penawaran tenaga kerja yang kemiringannya berjenjang mundur. Sebagaimana dijelaskan sebelumnya, selain sebagai tokoh utama dalam bidang sosiologi dari kalangan umat Islam, Ibn Khaldun juga membicarakan aspek- aspek ekonomi. Secara singkat akan dipaparkan pemikiran-pemikiran Ibn Khaldun tentang ekonomi antara lain:

\section{Mekanisme Pasar}

Ibn Khaldun secara khusus memberikan ulasan tentang harga dalam bukunya muqaddimah "Hargaharga di Kota". (Ibn Khaldun, terj., 2001 : 647-650). Ia membagi jenis barang menjadi dua jenis yaitu barang kebutuhan dan barang pelengkap. Menurutnya bila suatu kota berkembang dan populasinya bertambah banyak, maka pengadaan barang-barang kebutuhan pokok menjadi prioritas (Aditiawarman, 2008: 408)

Di lain pihak, permintaan terhadap barangbarang pelengkap akan meningkat sejalan dengan berkembangnya kota dan berubahnya gaya hidup. Dalam bahasa ekonomi kontemporernya, terjadi peningkatan disposable income dari penduduk kota dapat meningkatkan marginal propensity to consumen terhadap barang-barang mewah dari setiap penduduk kota tersebut. Hal ini menciptakan permintaan baru terhadap barang- 
barang mewah. Akibatnya barang-barang mewah akan meningkat pula (Amalia, 2010: 238).

Naik turunnya sebuah permintaan terhadap suatu barang, menurut Ibn Khaldun berdampak terhadap harga. Ketika barang-barang yang tersedia sedikit maka harga akan naik. Namun bila jarak antar suatu kota dekat dan aman untuk melakukan perjalanan, maka akan banyak barang yang dapat diimpor sehingga ketersediaan barang akan melimpah, dan harga akan turun. Dengan demikian Ibn Khaldun telah mengidentifikasi kekuatan permintaan dan penawaran sebagai penentu keseimbangan harga.

Harga adalah hasil dari hukum permintaan dan penawaran. Penentuan harga dilakukan oleh kekuatan-kekuatan pasar yaitu kekuatan permintaan dan kekuatan penawaran. Pertemuan permintaan dengan penawaran tersebut haruslah terjadi secara rela sama rela (saling rela). Pada tingkat harga tersebut, tidak ada pihak yang merasa terpaksa untuk melakukan transaksi pada tingkat harga tersebut (Suprayitno, 2005: 187).

Dalam penentuan harga di pasar terhadap sebuah produksi, faktor yang sangat berpengaruh adalah permintaan dan penawaran. Ibn Khaldun menekankan bahwa kenaikan penawaran atau penurunan permintaan menyebabkan kenaikan harga, demikian pula sebaliknya penurunan penawaran atau kenaikan permintaan akan menyebabkan penurunan harga. Penurunan harga yang sangat drastis akan merugikan pengrajin dan pedagang serta mendorong mereka keluar dari pasar, sedangkan kenaikan harga yang drastis akan menyusahkan konsumen. Harga damai dalam kasus seperti ini sangat diharapkan oleh kedua belah pihak, karena ia tidak saja memungkinkan para pedagang mendapatkan tingkat pengembalian yang ditolerir oleh pasar dan juga mampu menciptakan kegairahan pasar dengan meningkatkan penjualan untuk memperoleh tingkat keuntungan dan kemakmuran tertentu. Akan tetapi, harga yang rendah dibutuhkan pula, karena memberikan kelapangan bagi kaum miskin yang menjadi mayoritas dalam sebuah populasi.

Dengan demikian, tingkat harga yang stabil dengan biaya hidup yang relatif rendah menjadi pilihan bagi masyarakat dengan sudut pandang pertumbuhan dan keadilan dalam perbandingan masa inflasi dan deflasi. Inflasi akan merusak keadilan, sedangkan deflasi mengurangi insentif dan efisiensi. Harga rendah untuk kebutuhan pokok seharusnya tidak dicapai melalui penetapan harga baku oleh negara karena hal itu akan merusak insentif bagi produksi.

Faktor yang menetapkan penawaran, menurut Ibn Khaldun, adalah permintaan, tingkat keuntungan relatif, tingkat usaha manusia, besarnya tenaga buruh termasukilmu pengetahuan dan keterampilan yang dimiliki, ketenangan dan keamanan, dan kemampuan teknik serta perkembangan masyarakat secara keseluruhan. Jika harga turun dan menyebabkan kebangkrutan modal menjadi hilang, insentif untuk penawaran menurun, dan mendorong munculnya resesi, sehingga pedagang dan pengrajin menderita. Pada sisi lain, faktor-faktor yang menentukan permintaan adalah pendapatan, jumlah penduduk, kebiasaan dan adat istiadat masyarakat, serta pembangunan dan kemakmuran masyarakat secara umum (Chapra, 2001: 166). 
Pengecualian satu-satunya dari hukum ini adalah harga emas dan perak (yang merupakan standar moneter). Semua barang-barang lainnya bisa terkena fluktuasi harga yang tergantung pada pasar. Apabila suatu barang terjadi kelangkaan dan banyak permintaan, maka harga cenderung tinggi. Jika suatu barang berlimpah, maka harganya cenderung rendah. Oleh karena itu, Ibn Khaldun menguraikan teori nilai yang berdasarkan tenaga kerja, sebuah teori tentang uang yang kuantitatif dan sebuah teori tentang harga yang ditentukan oleh hukum permintaan dan penawaran.

\section{Keuntungan}

Keuntungan menurut Ibn Khaldun adalah nilai yang timbul dari kerja manusia yang diperoleh dari usaha untuk mencapai barang-barang dan perhatian untuk memilikinya. Oleh karena itu kerja, manusia merupakan elemen penting dalam proses produksi (Amalia, 2005: 241).

Nilai suatu produk sama dengan jumlah tenaga kerja yang dikandungnya. Demikian pula, kekayaan bangsa tidak ditentukan oleh jumlah uang yang dimiliki bangsa tersebut, tetapi ditentukan oleh produksi barang dan jasanya dan ditentukan pula oleh neraca pembayaran yang sehat. Neraca pembayaran yang sehat merupakan konsekuensi alamiah dari tingkat produksi yang tinggi (Abdullah, 2010: 290).

Teori nilai kerja Ibn Khaldun ini kemudian juga diungkapkan oleh David Ricardo (17721883) empat abad kemudian. Dalam teorinya tentang nilai kerja dan upah alami, Ricardo menjelaskan bahwa nilai tukar suatu barang ditentukan oleh ongkos yang perlu dikeluarkan untuk menghasilkan barang tersebut, yaitu biaya untuk bahan mentah dan upah buruh yang besarnya hanya cukup untuk bertahan hidup bagi buruh yang bersangkutan. (Deliarnov, 2003:53)

Dalam hal ini Ricardo lebih menekankan pada maksimalisasi hasil produksi dan minimalisasi ongkos produksi dengan memberikan upah minimum bagi buruh. Hal ini berlawanan dengan konsep Ibn Khaldun yang menghargai kerja manusia dalam proses produksi, sehinga gaji, upah dan keuntungan bagi pekerja yang didapat dari hasil produksi harus sesuai dengan kualitas yang dimiliki buruh tersebut.

Dengan demikian Ibn Khaldun mengemukakan bahwa nilai sesuatu itu terletak pada kerja manusia yang dicurahkan kepadanya, atau dengan kata lain substansi nilai itu adalah kerja, dan segala yang terpenting dalam kerja tersebut adalah pencurahan tenaga untuk memproduksi sesuatu yang dapat memenuhi kebutuhan masyarakat. (Amalia, 2005: 241). Sebagaimana yang dikatakan oleh Khalifah Ali bahwa nilai setiap orang terletak pada keahlian yang dimilikinya.

Dalam konsep keuntungan Ibn Khaldun, nilai kerja menempati poin sentral dalam teori produksi, ia mengaharuskan dalam setiap penentuan biaya produksi, biaya tenaga kerja harus dimasukkan ke dalamnya karena adanya usaha dan kerja, laba dan keuntungan akan diperoleh, bila tidak ada kerja maka tidak akan ada produksi.

\section{Division of labor dan Perdagangan Internasional}

Ibn Khaldun berpendapat bahwa apabila pembagian pekerjaan kepada masyarakat berdasarkan kepada spesialisasi dan keahlian masyarakat tersebut, maka menurutnya akan menghasilkan output yang lebih besar. Konsep ini 
berdampak terhadap adanya peningkatan hasil dari suatu produksi. Dan sebagaimana teori division of labor-nya Adam Smith (1729-1790), bahwa pembagian kerja akan mendorong spesialisasi, dimana orang akan memilih pekerjaan yang terbaik sesuai dengan bakat dan kemampuan yang dimiliki oleh masing-masing pekerja. Hal ini akan meningkatkan produktivitas dari tenaga kerja, dan pada akhirnya akan dapat meningkatkan hasil produksi secara total (Deliarnov, 2003: 36).

Ibn Khaldun menyarankan adanya kerja sama yang saling menguntungkan dalam memenuhi kebutuhan ekonomi. Dalam teori ekonomi modern teori ini dikenal dengan teori comparative advantage. Selain itu melalui spesialisasi dan kerja sama sosial, maka kinerja manusia menjadi berlipat ganda. Produksi agregat yang dihasilkan oleh manusia yang bekerja sama akan lebih besar bila dibandingkan dengan jumlah total produksi individu dari setiap orang yang bekerja secara individu dan lebih besar pula dibandingkan dengan jumlah yang dibutuhkan mereka untuk dapat bertahan hidup. Ada surplus yang tersisa yang dapat digunakan untuk diperdagangkan.

Oleh karena itu, Ibn Khaldun menganjurkan sebuah organisasi sosial dari produksi dalam bentuk suatu spesialisasi kerja. Produktivitas yang tinggi hanya akan didapatkan dari spesialisasi kerja, dan memungkinkan terjadinya suatu surplus dan perdagangan antara para produsen.

Lalu apa hubungan division of labor dengan perdagangan internasional. Teori division of labor merupakan embrio dari teori perdagangan internasional. Hal itu didasari analisisnya tentang pertukaran atau perdagangan di antara negara- negara miskin dan negara kaya yang menimbulkan kecenderungan suatu negara untuk mengimpor atau mengekspor dari negara lain. Alur berpikirnya terlihat bahwa Division of labor akan menghasilkan produksi maksimum sehingga negara tidak hanya mencapai swasembada terhadap suatu kebutuhan barang, tetapi juga mempunyai kelebihan supply. Hal ini memungkinkan negara untuk mengekspor barang ke luar negeri. Maka terjadilah perdagangan internasional. Hal lainnya adalah karena dengan adanya division of labor negara juga akan lebih efisien dalam proses produksi. Dengan rendahnya biaya produksi maka harga produk tersebut akan kompetitif ketika masuk ke pasar luar negeri.

Teori tentang division oflabor ini menunjukan konsistensi pemikiran Ibn Khaldun tentang bagaimana menciptakan kesejahteraan negara. Untuk menjadi sejahtera negara harus menggenjot sisi produksi domestik. Hal ini ditujukan agar negara swasembada dan dapat mengekspor ke luar negeri. Ekspor akan meningkatkan devisa negara sehingga neraca pembayaran negara akan positif. Dengan begitu kekayaan negara akan meningkat dan kemakmuran rakyat akan terciptakan. Salah satu yang harus dilakukan sebagai upaya maksimalisasi dan efisiensi produksi adalah dengan melakukan division of labor.

\section{Keuangan Publik}

Pemerintah tidak dapat menciptakan uang. Uang yang dibelanjakan oleh pemerintah berasal dari penduduk melalui pajak. Pajak sebagai sumber pemasukan negara harus dikelola dengan baik sehingga dapat memberikan hasil yang maksimal dan nantinya bisa digunakan 
untuk memperbaiki kesejahteraan sosial rakyat. Karena itulah menurut Ibn Khaldun keberadaan departemen perpajakan sangat penting bagi kekuasaan raja. Departemen ini berkaitan dengan operasional perpajakan dan memelihara hakhak negara terkait pendapatan dan pengeluaran negara (Ibn Khaldun, 2000: 249).

Perekonomian yang meningkat di awal pemerintahan akan mendatangkan pajakyanglebih tinggi dari tarif pajak yang lebih rendah, sementara perekonomian yang depresi akan mendatangkan pajak yang lebih rendah dengan tarif yang lebih tinggi. Alasan terjadinya hal tersebut adalah rakyat yang mendapatkan perlakuan tidak adil dalam kemakmuran mereka akan mengurangi keinginan mereka untuk menghasilkan dan memperoleh kemakmuran. Ketika rasa keinginan itu hilang, maka mereka akan berhenti bekerja karena semakin besar beban maka akan semakin besar efek terhadap usaha mereka dalam berproduksi.

Akhirnya, jika rakyat enggan menghasilkan dan bekerja, maka pasar akan mati dan kondisi rakyat akan semakin memburuk serta penerimaan pajak juga akan menurun. Oleh karena itu, Ibn Khaldun menganjurkan keadilan dalam perpajakan. Pajak yang adil sangat berpengaruh terhadap kemakmuran suatu negara. Kemakmuran cenderung bersirkulasi antara rakyat dan pemerintah, dari pemerintah ke rakyat, dan dari rakyat ke pemerintah, sehingga pemerintah tidak dapat menjauhkan belanja negara dari rakyat karena akan mengakibatkan rakyat menjauh dari pemerintah.

Uang yang dibelanjakan oleh pemerintah berasal dari penduduk melalui pajak. Pemerintah dapat meningkatkan pengeluarannya hanya dengan meningkatkan pendapatan dari sektor pajak. Akan tetapi tekanan fiskal yang terlalu tinggi akan melemahkan semangat orang dalam bekerja. Akibatnya kemudian, timbul siklus fiskal. Pemerintah memungut pajak yang kecil dan penduduk memiliki laba yang besar. Pada gilirannya, mereka semangat untuk bekerja, namun kebutuhan pemerintah serta tekanan fiskal naik. (Karim, 2006: 394-412).

Penetapan pajak yang berprinsip pada keadilan merupakan suatu keharusan. Ibn Khaldun menegaskan bahwa penetapan dan pembebasan pajak harus sesuai dengan syariah, seperti sedekah, pajak tanah, kharaj,jizyah, dan lain-lain. Semua itu memiliki batas yang tetap dan tidak bisa dilebihkan (Ibn Khaldun terj, 2000: 348).

Ia menggambarkan bagaimana pengaruh pajak terhadap insentif dan produktivitas. Ia menyimpulkan bahwa faktor terpenting untuk prospek usaha adalah dengan meringankan beban pajak bagi pengusaha untuk menggairahkan kegiatan bisnis, dengan menjamin keuntungan yang lebih besar setelah pajak. Ibn Khaldun juga menganalisa efek dari pengeluaran belanja pemerintah dalam perekonomian bahwa penurunan dalam penghasilan pajak disebabkan juga oleh penurunan belanja pemerintah. Alasannya karena negara adalah pasar yang paling besar, dasar semua perdagangan, substansi dari pemasukan dan pengeluaran.

Jika pemerintah menimbun penerimaan pajak, atau jika mereka tidak bisa membelanjakan sebagaimana mestinya, jumlah uang yang tersedia yang sampai ke pegawai-pegawai pemerintah (upah) akan menurun. Hal ini tentu berlanjut hingga 
ke berbagai lapisan masyarakat (multiplier effect), sehingga total belanja mereka akan menurun. Untuk itulah Ibn Khaldun menekankan peranan investasi.

\section{Standar Kekayaan Negara}

Menurut Ibn Khaldun kakayaan sebuah negara tidak ditentukan oleh banyaknya uang di negara tersebut, tetapi kekayaan negara ditentukan oleh tingkat produksi domestik dan neraca pembayaran yang positif dari negara tersebut (Karim, 2006: 190).

Dengan demikian, negara yang makmur adalah negara yang mampu memproduksi lebih banyak dari yang dibutuhkan, sehingga kelebihan hasil produksi tersebut diekspor, dan pada akhirnya akan menambah kemakmuran di negara tersebut. Berikut merupakan konsep ekonomi menurut Ibn Khaldun sebagai indikator dari kekayaan suatu negara:

\section{Tingkat Produk Domestik Bruto}

Bila suatu negara mencetak uang dengan sebanyak-banyaknya, itu bukan merupakan refleksi dari pesatnya pertumbuhan sektor produksi (baik barang maupun jasa). Maka uang yang melimpah itu tidak ada artinya, yang membuat jumlah uang lebih banyak dibanding jumlah ketersediaan barang dan jasa. Sektor produksilah yang menjadi moto pembangunan, menyerap tenaga kerja, meningkatkan pendapatan pekerja, dan menimbulkan permintaan atas faktor produksi lainnya (Amalia, 2005: 245).

\section{Neraca Pembayaran Positif}

Ibn Khaldun menegaskan bahwa neraca pembayaran yang positif akan meningkatkan kekayaan negaratersebut. Neraca pembayaran yang positif menggambarkan dua hal : a. Tingkat produksi yang tinggi.

Jika tingkat produksi suatu negara tinggi melebihi dari jumlah permintaan domestik negara tersebut, atau supply lebih besar dibanding demand. Maka memungkinkan negara tersebut melakukan kegiatan ekspor.

b. Tingkat efisiensi yang tinggi

Bila tingkat efisiensi suatu negara lebih tinggi dibanding negara lain, maka dengan tingkat efisiensi yang lebih tinggi maka komoditi suatu negara mampu masuk ke negara lain dengan harga yang lebih kompetitif.

Untuk bisa bersaing di pasar luar negeri, negara harus mengupayakan efisiensi dalam proses produksi, dengan begitu harga barangyang diekspor tersebut akan mampu bersaing dipasar luar negeri. Efisiensi dapat dilakukan salah satunya dengan melihat keunggulan negara terhadap negara lain dalam hal produksi. Dalam teori modern disebut comparative advantage. Negara harus menganalisa dimana keunggulan mereka. Misalnya negara dengan tanah subur mempunyai keunggulan dalam hal pertanian sehingga tidak perlu memaksakan diri memproduksi pesawat terbang atau kereta api. Dengan begitu negara akan lebih efisien dalam hal produksi dan produksi negara akan menciptakan neraca pembayaran positif.

\section{Konsep Uang}

Ibn Khaldun mengemukakan bahwa emas dan perak selain berfungsi sebagai uang juga digunakan sebagai medium pertukaran dan alat pengukur nilai sesuatu. Uang itu tidak harus mengandung emas dan perak, hanya saja emas dan perak dijadikan standar nilai uang, sementara pemerintah menetapkan harganya secara konsisten. Oleh 
karena itu Ibn Khaldun menyarankan agar harga emas dan perak itu konstan meskipun harga-harga lain berfluktuasi (Karim, 2001: 4).

Berdasarkan pendapat Ibn Khaldun di atas, sebenarnya standar mata uang yang ia sarankan masih merupakan standar emas hanya saja standar emas dengan sistem the gold bullion standard, yaitu ketika logam emas bukan merupakan alat tukar namun otoritas moneter menjadikan logam tersebut sebagai parameter dalam menentukan nilai tukar uang yang beredar. Koin emas tidak lagi secara langsung dipakai sebagai mata uang. Dalam sistem ini, diperlukan suatu kesetaraan antara uang kertas yang beredar dengan jumlah emas yang disimpan sebagai backup. Setiap orang bebas memperjualbelikan emas, tetapi pemerintah menetapkan harga emas.

Di sini terlihat ketajaman analisis Ibn Khaldun tentang standar mata uang dengan memprediksi tentang perkembangan perekonomian. Dilihat perkembangan perekonomian zaman sekarang hal ini terbukti bahwa untuk penetapan mata uang harus berpijak pada standar dari mata uang yang ditetapkan oleh pemerintah.

\section{Kesejahteraan Masyarakat}

Kesejahteraan dan pembangunan, menurut Ibn Khaldun bergantung pada aktivitas ekonomi, jumlah dan pembagian tenaga kerja, luasnya pasar, tunjangan dan fasilitas yang disediakan negara, serta peralatan. Pada gilirannya tergantung pada tabungan atau surplus yang dihasilkan setelah memenuhi kebutuhan masyarakat. Semakin banyak aktivitas yang dilakukan, maka negara akan semakin besar. Pendapatan yang besar akan memberikan kontribusi terhadap tingkat tabungan yang lebih tinggi dan investasi yang lebih besar untuk peralatan dan dengan demikian akan ada kontribusi yang lebih besar di dalam pembangunan dan kesejahteraan (Amalia, 2005: 249).

Ketika tingkat pendapatan dan kesejahteraan tinggi, hal ini akan memberikan kontribusi terhadap kenaikan penadapatan pajaksehingga memungkinkan pemerintah mengeluarkan anggaran yang lebih untuk kesejahteraan rakyat. Alat untuk mencapai kesejahteraan dan pembangunan yang paling utama menurut Ibn Khaldun adalah masyarakat, pemerintah, dan keadilan. Di masyarakat, solidaritas diperlukan untuk meningkatkan kerja sama, sehingga akan meningkatkan produktivitas, solidaritas akan menguat jika ada keadilan. Dalam kesempatan lain, Ibn Khaldun juga mengungkapkan bahwa faktor ekonomi, kebersihan, moral dan sosial mempengaruhi jumlah populasi masyarakat, dan populasi yang besar akan menciptakan kesejahteraan.

\section{PENUTUP}

Dari paparan di atas memperlihatkan kualitas Ibn Khaldun sebagai seorang pemikir dan juga praktisi. Ia banyak memberi ide dan pemikiran tentang penyelenggaran negara dalam rangka menciptakan kesejahteraan rakyat. Teori- teori Ibn Khaldun sangat komprehensif membahas kesejahteraan negara karena kedalaman ilmu pengetahuan yang ia miliki dan pengalaman menempati beberapa posisi dipemerintahan. Ibn Khaldun menemukan banyak pemikiranpemikiran ekonomi. Ia menemukan manfaat dan perlunya pembagian kerja sebelum teori Smith dan prinsip nilai tenaga kerja sebelum Ricardo. Namun lebih dari sekedar itu semua, Ibn 
Khaldun menggunakan konsep-konsep ini untuk membangun suatu sistem yang dinamis dan koheren. Dalam sistem ini mekanisme ekonomi tidak dapat membawa aktivitas ekonomi kepada fluktuasi jangka panjang. Karena koherensi sistemnya, kritik yang dapat dilancarkan terhadap kebanyakan konsep-konsep ekonomi yang menggunakan ide yang sama.

Inti dari ajaran Ibn Khaldun adalah bagaimana menciptakan welfare state atau negara yang penduduknya sejahtera. Untuk bisa terwujudnya Negara sejahtera maka ada beberapa teori yang dikembangkan, yaitu:

1. Mekanisme Pasar, yang mengambarkan bahwa kekuatan permintaan dan penawaran sebagai faktor penentu untuk keseimbangan harga.

2. Keuntungan, sebuah nilai yang akan timbul dari kerja manusia. Nilai suatu produk sama dengan jumlah tenaga kerja yang dikandungnya. Demikian pula, kekayaan bangsa tidak ditentukan oleh jumlah uang yang dimiliki bangsa tersebut, tetapi ditentukan oleh produksi barang dan jasanya dan ditentukan pula oleh neraca pembayaran yang sehat.

3. Division of labour, spesialisasi dan keahlian msyarakat akan menghasilkan output yang lebih besar. Konsep ini berdampak terhadap adanya peningkatan hasil dari suatu produk, ketika pekerjaan tersebut diserahkan kepada ahlinya.

4. Keuangan Publik, berasal dari pajak. Penetapan pajak yang berprinsip pada keadilan merupakan suatu keharusan. Ibnu Khaldun menegaskan bahwa penetapan dan pembebasan pajak harus sesuai dengan syariah, seperti sedekah, pajak tanah, kharaj, jizyah, dan lain-lain. Semua itu memiliki batas yang tetap dan tidak bisa dilebihkan.

5. Standar Kekayaan Negara, Menurut Ibn Khaldun kakayaan sebuah negara tidak ditentukan oleh banyaknya uang di negara tersebut, tetapi kekayaan negara ditentukan oleh tingkat produksi domestik dan neraca pembayaran yang positif dari negara tersebut.

6. Standar mata uang dengan memprediksi tentang perkembangan perekonomian. Dilihat perkembangan perekonomian zaman sekarang hal ini terbukti bahwa untuk penetapan mata uang harus berpijak pada standar dari mata uang yang ditetapkan oleh pemerintah.

7. Kesejahteraan masyarakat, teorinya tentang produksi yang didalamnya membahas masalah pembagian kerja dan efisiensi menjelaskan pada negara bahwa proses produksi harus terus ditingkatkan untuk meningkatkan kekayaan negara. Produksi maksimum akan memungkinkan swasembada dan kelebihan supply yang kemudian biasa dijual di pasar luar negeri. Ekspor barang akan membuat neraca pembayaran Negara positif dan kesejahteraan rakyat meningkat.

\section{DAFTAR KEPUSTAKAAN}

Abdullah, Boedi, 2010. Peradaban Pemikiran Ekonomi Islam, Bandung: Pustaka Setia

Amalia, Euis, 2010. Sejarah Pemikiran Ekonomi Islam, Depok: Gramatapublishing

Chapra, Umer, 2001. Masa Depan Ilmu Ekonomi Sebuah tinjauan Islam, The Future of Economic an Islamic Perspective, Jakarta; Gema Insani Press 
Deliarnov, 1995. Perkembangan Pemikiran Ekonomi, Jakarta : Rajawali Press

Hendrieanto, 2003, Pengantar Ekonomi Makro Islami, cet ke- 1, Yogyakarta; Ekonisia

Karim, Adiwarman Azwar, 2003, Ekonomi Mikro Islami. Edisi Kedua. Jakarta: IIIT

-------, Adiwarman Azwar, 2006. Sejarah Pemikiran Ekonomi Islam, Jakarta:Raja Grafindo Persada

Khaldun, Ibn, 2000. Muqaddimah Ibn Khaldun, alih bahasa Ahmadie Thoha, cet. 2, Jakarta: Pustaka Firdaus
Suprayitno, Eko, 2005. Ekonomi Islam; Pendekatan Ekonomi Makro Islam dan Konvensional, Yogyakarta : Graha Ilmu

Sutan Remy, Sjahdeini, 2014, Perbankan Syariah : Produk-Produk dan aspek Hukumnya, Jakarta: Kencana Prenadamedia Group

Wafi, Ali Abdul, Wahid, 1985, Ibnu Khaldun : Riwayat Hidup dan Karyanya Pent. Ahmadi Thaha, (Jakarta : Grafiti Press, 1985) 